\title{
VALENŢE FORMATIVE ALE EDUCAȚIEI RELIGIOASE ÎN MODELAREA PERSONALITĂŢII TINEREI GENERAŢII POSTMODERNE
}

\author{
Motto: „Dacă pentru om este important destinul lui etern, \\ înseamnă că educaţia nu poate ignora această temă importantă" \\ (Garrido, 1995)

\section{Florentin-Remus Mogonea* Florentina Mogonea**}

\begin{abstract}
The present study aims to prove the importance of the formative valence of the religious education, in forming and development of the moral conscience and conduct of the young generation, in the context of major changes, brought by postmodernism. Thus, we will try to identify solutions, pertinent arguments, strategies and methods of attracting the young generations to come close to the authentic Christian values, reunited under the sign of infinite love of Jesus Christ for people.

We consider important the youth relationship with Divinity because starting with adolescence (even preadolescence) the forming of the self-image in the spirit of religious, sacred values, helps him/her to overcome easier the daily obstacles by meditation, humility, prayers. Faith in God has a spiritual weight and offers to youth trust in own forces.

Religious faith proves to be essential in offering a goal and defining the people desires, aspirations, thoughts and actions. For many young people that do not refuse the religious experience and search the basis of faith values, religion and spirituality proved to be important sources of hope, ideals and life models that can influence the course of their identity development in the adolescence period. It is necessary a permanent dialog with young generations that are opened to the spiritual life or are searching it. Thus, there is the risk to find it in another part, to stop from their searches being disappointed or blasé or to be satisfied with authenticity appearances.
\end{abstract}

* Associate Professor, Ph.D, Department of Teacher Training, University of Craiova, Romania.

** Associate Professor, Ph.D, Department of Teacher Training, University of Craiova, Romania. 
In our study, we plead for a religious education of the youth, which should not be regarded as competitive with other sides of the education, but global, integrated. The actual pedagogy emphasizes the necessity of forming and molding the harmonious personality of the educable youth, an important contribution also bringing the religious education in reaching the general goals, pursuing the complementary and continuity in informative and, especially, formative plan.

Keywords: formative valence, postmodernism, religious education, youth personality molding.

\section{Introducere. Caracteristici ale postmodernităţii}

Termenul de postmodernism - apreciază Crenguța Oprea apare pentru prima dată în 1870, într-un context artistic, când pictorul englez John Watkins Chapman utiliza sintagma ,pictură postmodernistă", pentru a denumi fenomenul plastic european ulterior picturii impresioniste. Către mijlocul secolului al XX-lea termenul capătă o evoluţie spectaculoasă, extinzându-se în diferite domenii, instaurând un nou stadiu al istoriei. Postmodernismul nu este, deci, doar o mişcare filozofică; el poate fi regăsit, de asemenea, în arhitectură, în grafică, în arta dansului, în muzică, în arta şi teoria literară şi devine în prezent subiectul predilect al multor autori (psihologi, sociologi, pedagogi, filosofi, literaţi), deoarece toate palierele soci-economicului sunt bulversate de efectele sale.

În lumea actuală, postmodernismul aduce noi ierarhii, teorii, noi ordini şi preferinţe. Valorile epocii moderne sunt luate în derâdere şi sunt reconsiderate şi revalorificate dintr-o nouă perspectivă Postmodernismul proclamă diversitatea, eclectismul. Relaţiile dintre oameni se schimbă, puterea banului ia amploare şi declanşează urmărirea intereselor personale, diminuând respectul pentru sine şi pentru alţii (Lipovetsky, 1996, p. 168). Multiculturalismul, interculturalismul, transculturalismul devin direcţii aclamate de postmodernism, tinzându-se spre holism cultural, globalizare, geomodernism. Cartea nu mai este apreciată în absolut, pierzându-şi valoarea de „obiect” singular propagator de cultură peste timp, omul postmodern fiind atras de lumea imaginii vii şi colorate a televizorului sau, mai ales, de lumea imaginii virtuale a 
calculatorului. $\mathrm{Nu}$ trebuie înţeles că toate aceste modificări au neapărat aspect şi efecte negative. Ce trebuie subliniat însă, este faptul că largheţea din interiorul fiecărui departament în parte şi dintre toate compartimentele axiologiei duce la o mai mare libertate de mişcare în interiorul lor a indivizilor - lucru evident pozitiv - care libertate însă oferă posibilitatea de a glisa cu uşurinţă între coduri axiologice diferite, chiar opuse, ca modalitate de subterfugiu - şi aici efectele negative sunt evidente.

Tânărul erei noastre poate îmbrăţişa cu mult aplomb, în virtutea principiilor postmoderne, subcultura (sub)urbană, alunecând, de multe ori fără să-şi dea seama şi iremediabil, în braţele voluptoase ale drogurilor, alcoolismului, violenţei juvenile, a luptelor de stradă, ludicului electronic sau artei video. De multe ori, tânărul însuşi, prins în mrejele unei astfel de lumi în care crede cu stoicism, nu poate să-şi dea seama de ce greşeşte, de ce lumea îl dezaprobă. În acest caz, se adânceşte şi mai mult în propria-i debusolare axiologică, luând-o ca modalitate de fiinţare culturală, creându-şi coduri axiologice proprii, denaturate, de a căror existenţă factorii tutelari educativi nu au cunoştinţă. (Maliţa, 1998, p. 93-108; Cucoş, 2000, p.74-78). Sintetizând concepţiile mai multor teoreticieni ai acestui curent (D. Harvey, Z. Bauman, I. Hassan, R. Williams, D. Bell, G. Graff, JeanFrancois Lyotard, M. Călinescu etc.), Elena Macavei (2001, p. 1619) stabileşte comparativ trăsăturile postmodernismului în relaţie cu cele ale modernismului:

Modern: raţionalitate, rigoare logică, delimitare riguroasă, determinare, certitudine, încadrarea într-un stil, conformism, fixitate, permanent, imitare, continuitate, centralizat, unitar, conveniență, certitudine, cultural, determinare.

Postmodern: conduită ludică, alternative, variante, renunţarea la limite, graniţe, indeterminare, ambivalenţă, amestecul stilurilor, contestare, rebeliune, mobilitate, efemer, imediat, originalitate, discontinuitate, descentralizat, fragmentar, toleranţă, incertitudine, intercultural, indetermanenţă (concept alcătuit, în opinia lui Ihab Hassan, din indeterminare şi imanenţă).

Într-o astfel de eră de profunde transformări, într-o societate „deschisă” şi democratică, ce îşi creează şi re-creează continuu noi 
coduri axiologice născute sau nu din codurile axiologice ale unei societăţi ,închise”, premergătoare, (Bergson., apud Albu, 1998, p. 940), rolul educaţiei este foarte dificil, iar orientarea axiologică a tinerilor se loveşte de numeroase obstacole. Iată de ce şcoala şi familia trebuie să-i înveţe pe tineri să-şi trăiască cu adevărat tinerețea, o tinerețe lipsită de iluziile sau halucinaţiile oferite de droguri şi alcoolism, dar şi de plăcerile momentane ale unei lumi virtuale. Şcoala şi familia sunt două instituţii cu rol diriguitor în orientarea axiologică a tinerilor. Educaţia formală şi nonformală trebuie să domine influenţele educative, adesea nefaste, ale educaţiei străzii, ale educaţiei informale, difuze, spontane. Acest lucru este posibil numai printr-un efort comun al factorilor educativi, căci, se ştie, e mai uşor să previi, decât să corectezi. Cooperarea dintre familie şi şcoală este o cerinţă de prim rang. Numai efortul conjugat al acestora poate duce la rezultate pozitive şi poate feri tinerii de o tinerețe fără tinerețe.

\section{Educaţia religioasă faţă în faţă cu provocările postmodernităţii}

Tinerii din zilele noastre sunt puternic influenţaţi de valorile propuse de lumea postmodernă. Adesea ei sunt îndepărtaţi de valorile adevărate propuse de religia creştină şi datorită procesului de răsturnare a valorilor şi de aprobare a kitschului. Considerăm mai importantă relaţia tinerilor cu Divinitatea, întrucât începând cu adolescența, (chiar preadolescența) formarea imaginii de sine în spiritul valorilor religioase sacre, îl ajută pe acesta să depăşească mai uşor, prin, meditaţie, smerenie, rugăciuni obstacolele cotidiene. Credinţa în Dumnezeu are o încărcătură spirituală şi conferă tânărului încredere în propriile forţe. Dar când lumea materială, limitată şi trecătoare este folosită în mod egoist şi pragmatic ca şi când ar fi singura realitate şi sursă de fericire a omului, atunci se produce în societate o profundă criză spirituală, iar tinerii sunt, cel mai adesea, cei mai afectaţi de această criză.

Credinţa religioasă se dovedeşte esenţială în configurarea unui scop şi în conturarea dorinţelor, năzuinţelor, gândurilor şi 
acţiunilor oamenilor. Pentru mulţi tineri care nu refuză experienţa religioasă şi caută să cunoască temeiurile valorilor credinţei, religia şi spiritualitatea se dovedesc a fi surse importante de speranţă, idealuri şi modele de viaţă care pot influenţa cursul dezvoltării identităţii lor în perioada adolescenței.

Studiul religiozităţii tinerilor cunoaşte puţine cercetări în psihologia dezvoltării copilului, ceea ce pare surprinzător, dat fiind faptul că psihologi ca Stanley Hall au recunoscut că adolescenţa şi copilăria sunt perioade importante în dezvoltarea moral-religioasă. Dacă am defini spiritualitatea ca sete după dimensiunea transcendentă şi căutarea sensului, atunci cu siguranţă putem afirma că tinerii au puternice preocupări de natură spirituală: ei caută experienţa venerării şi uimirii uneori $\mathrm{cu}$ o intensitate pe care nici adulţii nu o depăşesc. (Neagu, http://ziarullumina.ro/adolescentii-sivalorile-credintei-10975.html, online, 11.04.2016).

\section{Promovarea valorilor religioase, premisă pentru o educaţie integrală}

$†$ †aniel, Patriarhul Bisericii Ortodoxe a României, (http://patriarhia.ro/tinerii-ortodocsi--marturisitori-ai-iubirii-luihristos-si-misionari-ai-bisericii-8189.html, online 11.04.2016) afirmă, pe bună dreptate, că „Într-o societate secularizată în care credinţa şi valorile spirituale sunt marginalizate, iar libertatea nu mai este asociată cu responsabilitatea, foarte mulţi tineri sunt debusolaţi, fără ideal, fără dorinţă de-a studia, fără dorință de-a munci, preferând să fie mereu ajutaţi financiar de către părinţi. La mulţi tineri se constată o ignoranță spirituală sau o abordare superficială a informaţiilor care privesc activitatea Bisericii sau viaţa spirituală a oamenilor. De asemenea, sunt tot mai mulţi tineri a căror principală preocupare intelectuală sau culturală se reduce la navigarea pe internet. Din acest motiv mulţi tineri devin victime ale manipulării de tot felul, induse de o anumită media, care promovează senzaţionalul şi nonvalorile."

De aceea, Patriarhul României, $\dagger$ Daniel, propune: 
1. O mai bună, puternică mobilizare a Bisericii, pentru a veni în întâmpinarea aspiraţiilor şi nevoilor tinerilor de azi:

„este absolut necesară o lucrare pastoral-misionară a Bisericii mai intensă şi mai vastă de îndrumare şi susţinere a tinerilor elevi, studenţi, a tinerilor căsătoriţi, a tinerilor care lucrează mult deşi primesc bani puţini, a tinerilor şomeri, care nu au un loc de muncă, oferindu-le asistenţă spirituală, pastorală şi social-caritabilă atât celor din România, cât şi celor din afara graniţelor acesteia."

2. Ajutor din partea Bisericii acordat tinerilor săraci sau în situaţia de a abandona studiile sau cei care doresc să migreze în alte ţări, pentru aflarea unui loc de muncă; ajutor acordat tinerilor orfani, abandonaţi; intensificarea iubirii părinţilor pentru copiii lor şi a copiilor pentru părinţi; cultivarea respectului şi a iubirii curate între tinerilor;

3. Conlucrarea dintre Biserică, şcoală şi familie pentru realizarea unei educaţii integrale, ştiinţifice şi spirituale, profesionale şi spirituale;

4. Biserica să cheme tinerii, pentru a putea fi mărturisitori ai iubirii lui Hristos pentru umanitate şi misionari ai Bisericii în lume, aşa cum Iisus Hristos i-a chemat pe ucenicii săi Săi la apostolat. „Adevăratul sens al misiunii tinerilor în Biserică este şi astăzi, ca şi în vremea Sfinţilor Apostoli: «să caute pacea cu toţi şi sfinţenia, fără de care nimeni nu va vedea pe Dumnezeu»" (Evrei 12, $14)$;

5. Cultivarea în Europa şi în lume valorile eterne ale Evangheliei iubirii lui Hristos şi ale demnităţii omului creat după chipul lui Dumnezeu.

Dar de ce acest segment de vârstă are nevoi de pastoraţie?! Părintele Ieromonah Nicodim Petre, într-un amplu studiu dedicat relaţiei tinerilor cu Biserica şi a nevoii chemării acestora în numele iubirii lui Iisus Hristos în sânul bisericii, răspunde edificator: [...]

„Pentru că este categoria de vârstă cea mai vulnerabilă; o vârstă a neștiinței, a naivității, a exuberanței fără rezerve. Tinerii sunt în multe cazuri ținta principală a reclamelor. Tineretul a devenit un segment 
social foarte expus astăzi în societate. Pe de altă parte, preocuparea vine din interior. Oricum, foarte adesea când citesc ceva legat de viața tinerilor îmi întăresc convingerea privind importanța ieșirii în întâmpinare întrebărilor şi căutărilor lor. Cred că după investiția în formarea preoților, a doua prioritate a Bisericii este investiția în tineri."

(https://www.monitorulsv.ro/Religie/2013-10-12/Tinerii-siBiserica-I, online, 11.04.2016). Şi continuă cu un alt argument convingător: „Toți tinerii au ceva în comun: căutarea. De altfel se zice că doar un tânăr în căutare este cu adevărat tânăr. Dar tinerii trebuie să fie ajutați în căutările lor. Este necesar un permanent dialog cu generațiile tinere care sunt deschise vieții spirituale sau care sunt în căutare. Altfel, este riscul să găsească în altă parte, să se oprească din căutările lor dezamăgiți sau blazaţi sau să se mulțumească doar cu aparențe de autentic. Pot eșua. De aceea suntem chemați să ieșim în întâmpinarea căutărilor tinerilor și să-i înțelegem chiar dacă ei înșiși la vârsta asta nu se înțeleg. Fiecare generație - spunea cineva - este un nou popor ce trebuie evanghelizat."

E. I. Gheorghiu (2003) arată în studiul „Religiozitate şi creştinism în România postcomunistă" că, în ultimele decenii, concomitent cu scăderea la nivel european a participării ;a manifestări religioase publice (a scăzut practica religioasă săptămânală, dar a crescut cea lunară şi de sărbători), a crescut nivelul manifestărilor religioase private, intrinseci.

Trebuie să recunoaştem, alături de alţi autori care au studiat fenomenul (Cucoş, 2009, p. 157-159) că, deşi un Marx, un Freud şi chiar un Nietzsche a au anunţat moartea religiei. Mai apăsat este cuvântul lui Nietzsche prin cunoscuta afirmaţie „Dumnezeu a murit!"' Tânărul zilelor noastre, în virtutea „dreptului omului”, uneori, forţează la limită o serie de libertăţi care merg până „la disipare şi dezorientare axiologic" (Cucoş, 2009, p. 157). Trăind întru spaţiu în care reperele sunt relative, tânărul devine un solitar,

${ }^{1}$ Ideea este preluată şi în Parabola nebunului din a sa carte Die fröhliche Wissenschaft (Ştiinţa veselă) din $1882 \mathrm{El}$ insistă, de fapt, asupra semnificaţiei pierderii credinţei. 
„ajutat” şi tehnologia modernă, mass-media, lumea tehnologiei si informaţiei, care bruschează relaţia e tip „face to face”. „Conglomerat dezinvolt de nevoi pasagere şi aleatorii, individul postmodern a uitat că libertatea este altceva decât puterea de a schimba o determinare, iar cultura este mai mult decât o pulsiune care trebuie satisfăcută." ( Finkienlkraut, 1987, p. 166, apud Cucoş, 2009, p. 158).

Or, tocmai aici înţelegem rostul şi rolul educaţiei religioase în postmodernitate: în a-1 educa pe tânăr, oferindu-i repere sigure într-o lume nesigură, atenuând scepticismul şi nihilismul, înlăturând ideea de autoeliminare fizică în virtutea unei blazări născută din lipsa de răspuns la o multitudine de întrebări. „Se moare din te miri ce: din plictis, din melancolie, din dureri imaginare; se moare în chip mistic, chiar" (Cucoş, 2009, p.158). Valadier (1989, p. 136) apreciază că Biserica poate juca ,un rol esenţial într-un univers marcat de nihilism, cu condiţia ca ea însăşi nu intre în jocul nihilismului: făcând din Dumnezeu un fundament, făcându-1 să se servească unor scopuri particulare sau captând în ea însăşi efectele gratuităţii. Sarcină dificilă, dar coerentă cu Evanghelia, unde servitorul trebuie să se retragă în faţă celui pe care îl serveşte. Servitor inutil al unei gratuităţi care nu are nevoie de noi, dar care ne face să semnificăm din interior asupra avariţiei noastre, care tocmai se converteşte în dar."

Religiozitate societăţilor actuale slăbeşte oarecum, fiind puternic afectată de îndepărtarea omului de natură, de sensurile primordiale ale vieţii. Cucoş (2009) şi Eliade (1992) vorbesc despre faptul că liturgia cosmică, misterul participării Naturii la drama cristologică au devenit inaccesibile omului care trăiesc într-un oraş modern. Omul modern apelează la religios împins de nevoi, circumstanţial, după caz, pragmatic. ca în pariul lui Pascal. ${ }^{2}$ Prin

\footnotetext{
${ }^{2}$ Pariul lui Pascal: Dacă crezi în Dumnezeu şi se dovedeşte ca El nu există, nu vei fi pierdut nimic, dar dacă nu crezi şi se dovedeşte că exista, vei merge în Iad. Aşadar, este iresponsabil să fii ateu. Mai formal, argumentul este structurat după cum urmează:

a. Nu ştim dacă există Dumnezeu.
} 
urmare, afectat de instabilitatea valorilor actuale, tânărului nu-i rămâne decăt să se agațe de cele spirituale, imuabile: „Să fim atenţi la aceste riscuri ale modernizării de dragul modernizării. Dacă vremurile sunt apocaliptice, religia trebuie să preîntâmpine vidul şi să se împotrivească hăului spiritual care se lărgeşte de la o zi la alta." (Cucoş, 2009, p. 159).

Într-o amplă cercetare sociologică pe un eşantion reprezentativ de adolescenţi transilvăneni, Dorin Oprişş şi Monica Opriş $(2015 \text {, p. 132-161) })^{3}$, în capitolul VI (,Biserica şi rolul acesteia în viaţa liceenilor",) ajunge la câteva concluzii pe care le considerăm pertinente:

Majoritatea elevilor (93.4\%) se roagă în lăcaşuri de cult la anumite intervale de timp. Chiar dacă rata de participare este mare, mai puţin de $1 / 5$ dintre aceştia se roagă săptămânal în spaţiul eclesial, mai precis, duminica; Aproape 1/3 dintre elevi (32.2\%) merg la Biserică cu o frecvenţă mai mică, respectiv o dată / de două ori pe lună. Mai mult de jumătate dintre elevi (50.7\%) merg la Biserică cel puţin o dată pe lună; cealaltă jumătate este constituită din adolescenţii care merg la Biserică doar la marile sărbători religioase (42.7\%) sau nu merg deloc (5.4\%)

În funcţie de gen, frecvenţa este mai mare la fete (59.67\%), faţă de băieţi (41.61\%);

- $\quad$ În funcţie de mediu de rezidenţă avem o pondere mai ridicată în mediul rural (59.32\%), faţă de mediul urban (42.29)

b. Dacă El există, necredinţa în El are consecinţe negative asupra sufletului nemuritor.

c. Dacă El nu există, credinţa în El nu are nici o consecinţă.

d. Aşadar, este în interesul omului să creadă în Dumnezeu.

${ }^{3}$ Într-un amplu studiu de cercetare dedicat valorilor agreate de adolescenţii din Transilvania, autorii se apleacă asupra unor teme de interes general cum ar fi relaţia valori - identitate de sine, familia la timpul prezent şi viitor, comunicarea şi comuniunea cu prietenii, şcoala şi perspectiva privind propria devenire, Biserica şi rolul acesteia în viaţa liceenilor, rolul altor instanţe educative în formarea şi dezvoltarea personală, viitoarea profesie: aşteptări şi preferinţe. 
Biserică;

Interesul scăzut pentru activităţile organizate de

- $\quad$ Deşi trăiesc în era vizualului, filmul religios nu şi-a găsit adepţi decât la un număr restrâns de tineri;

Numărul mic de propuneri pentru diferite activităţi la care elevii ar dori să participe se poate datora, fie lipsei implicării active în acţiuni diverse din care să-şi selecteze sau să-şi construiască propriile modele, fie dezinteresului pentru prezenţa mai activă în viaţa comunităţii religioase;

În consecinţă, pledăm pentru o educaţie religioasă a tinerilor care nu trebuie să fie văzută concurenţial, competiţional, în raport cu celelalte laturi ale educaţii, ci global, integrat. Pedagogia actuală subliniază necesitatea formării şi modelării personalităţii armonioase a tânărului educabil, un aport important aducându-şi şi educaţia religioasă în atingerea scopurilor generale, urmărindu-se complementaritatea şi continuitatea în plan informativ şi, mai ales, formativ. Constantin Cucoş (1999, p. 13) subliniază, pe aceeaşi direcţi, importanţa tratării laturilor educaţiei egalitarist şi, „,nu în chip autarhic, concurenţial, ci ca un demers, educaţional global, integrator, realizat cu profesionalism şi responsabilitate de către întreg personalul didactic."

Din punct de vedere al axiologiei creştine, valorile religioase au rol integrator, de liant între diferite elemente şi structuri cărora le imprimă pecetea eternităţii. Din acest punct de vedere Tudor Vianu, într-o lucrare deosebită afirma (1998, p. 117): „Valorile religioase sunt integrative. Ele integrează, unifică, constituie într-un tot solidar şi coerent toate valorile cuprinse de conştiinţa omului. Prin valorile religioase se înalţă arcul de boltă care uneşte valorile cele mai îndepărtate, adună şi adăposteşte pe cele mai variate. Un individ poate cuprinde diferite valori, pe cele mai multe din ele, dar legătura lor unificatoare va lipsi atâta timp cât valoarea religioasă nu li se adaugă”. Mari pedagogi, vorbind despre finalităţile educaţiei religioase, consideră că acestea pot fi atinse numai prin Raportare la Iisus Hristos: „Creştinii trebuie să fie formaţi după exemplul Lui, luminaţi în spirit, sfinţi în sârguinţa conştiinţei şi puternici în fapte (fiecare după vocaţia sa)". 
Ajungem, astfel la o concluzie mai mult decât evidentă: întro lume caracterizată de o tot mai mare diversitate etnică şi religioasă, educaţia religioasă propune cunoaşterea propriei identităţi, dar şi a celor de alte credinţe şi convingeri, favorizează incluziunea socială şi contribuie la depăşirea prejudecăţilor şi a oricăror forme de discriminare, aspect semnalat şi în lucrarea „Apostolat educaţional Ora de religie - cunoaştere şi devenire spirituală" (Pr. lect. dr. Gheorghe Holbea, Pr. lect. dr. Dorin Opriş, Lect. dr. Monica Opriş, Diac. George Jambore, 2010, p. 25).

Vorbind de rolul şi importanţa educaţiei religioase în rândul tinerilor, trebuie să semnalăm (aspect valabil în rândul tuturor iubitorilor de D-zeu, indiferent de vârstă) că educaţia religioasă se fundamentează pe un ansamblu de mecanisme şi demersuri sociale, culturale, antropologice chiar, care asigură formarea unor reprezentări corecte privind poziţia omului în societate şi în univers. Educaţia religioasă aduce răspunsuri clare la întrebări precum de unde venim, încotro ne îndreptăm, care este scopul şi menirea noastră în lume. Ea oferă tinerilor un sens vieţii, o alternativă care vizează Iubirea ca sentiment ce caracterizează iubirea fratelui, iubirea părinţilor, iubirea aproapelui, iubirea lui Dumnezeu şi a Fiului Său Iisus Hristos. Numeroase alte repere, modele şi reprezentări fundamentale sunt oferite de educaţia creştină: incursiuni în istoria şi cultura religioasă naţională şi universală, stimularea dialogului intercultural şi interconfesional (Cucoş, Constantin, 2002), din perspectiva libertăţii şi egalităţii între semeni, educarea în spiritul respectării drepturilor şi libertăţilor fundamentale ale omului, al toleranţei, demnităţii, al cultivării sensibilităţii faţă de problematica umană, faţă de valorile moral-civice, faţă de arte, natură, mediul înconjurător etc. Pr. lect. dr. Gheorghe Holbea, Pr. lect. dr. Dorin Opriş, Lect. dr. Monica Opriş, Diac. George Jambore, 2010, p. 25).

Încercarea ultimelor decenii în materie de pedagogie educaţională vizează, cu precădere, centrarea educaţiei oferită tinerilor exclusiv din perspectiva unei filosofii axiologice. Întoarcerea sau reîntoarcerea către valorile autentice, înseamnă şi recunoaşterea implicită a valorilor religioase care le-au impus, dar care, între timp, şi-au pierdut reprezentarea iniţială şi au cunoscut o 
uzură în timp, din cauza reevaluărilor, reinterpretărilor enclaviste, individualiste pragmatiste, nihiliste etc. Aşa cum afirma Constantin Cucoş (,Educaţie în perspectivă axiologică înseamnă a orienta procesul educativ pe traiectele cele mai profitabile sub aspectul eficienţei, a identifica sau a exploata momentele didactice privilegiate, a răspunde la toate căutările prin cele mai bune alegeri, [...] a acţiona în numele unei ordini de priorităţi”, 1996, p. 181), educaţia de tip axiologic (Joiţa, 1999) trebuie să se refere şi la axiologia religioasă, la care tinerii trebuie să aibă acces, ca o cale de acces către iubirea intru Dumnezeu.

\section{Ora de religie - necesitate a curriculumului naţional}

În România postcomunistă, revenirea la educaţia religioasă, respectiv la orele de religie ,nu trebuie considerată un act inovator, ci o revenire la normalitate" (Horga, 2005, p. 126 - 127). Altfel spus, reintroducerea orelor de religie pentru educarea tinerei generaţii nu ar trebui un element de reformă educaţională extraordinar, ci revenirea la făgaşurile normale de existenţă a individului şi a societăţii în ansamblul său. Cum omul tot timpul a fost preocupat de originile sale, de menirea sa existenţială încă din zorii umanităţii, este firesc să fie educat în spiritul valorilor religioase preţuite de strămoşii săi de milenii.

După ani grei de concepţie politico-socială marxist leninistă, începând cu 1989, în România, Biserica încetează să fie un ,ghetou liturgic" (IPS Daniel Ciobotea, 1995, p. 154), oferind mulţimii, în special tinerilor, modele de urmat, alternative misionare şi apostoliceşti. Dar, trebuie să recunoaştem că Biserica, în peisajul actual, trebuie să fie mai ofensivă, să se adapteze din mers schimbărilor, să înţeleagă necesităţile şi aspiraţiile tinerilor, să se implice mai mult, prin diverse mecanisme, parteneriate cu alte instituţii în multiple întreprinderi culturale şi sociale. Punând cele scrise mai sus în vorbele lui Émile Boutroux ( p.64), se poate afirma că: „Creştinismul trebuie, negreşit să se adapteze la viaţa reală, dacă vrea să fie altceva decât un vis sublim şi efemer, dacă vrea să devină el însuşi o realitate. Iar viaţa reală conţine: grija existenţei, a traiului 
bun şi a libertăţii exterioare, ştiinţa, filosofia, politica, artele, literele, cultul religios, într-un cuvânt, toate manifestările naturale şi toate formele tradiţionale ale activităţii omeneşti”.

Vorbind de religie ca disciplină de studiu în liceu, Constantin Cucoş $(2009 \text {, p. 38-40) })^{4}$, deşi pledează argumentat pentru o educaţie religioasă la vârstele timpurii, chiar ale preşcolarităţii, identifică şi câteva modalităţi concrete de realizare pentru tinerii adolescenţi, prezentând, în acelaşi timp, şi punctele slabe ale ofertei sale:

- $\quad$ Structurarea unui curriculum religios, fără coloratură confesională, centrat pe elemente istorice, filosofice, comparative, adiacente oricărui edificiu religios;

- Alcătuirea unui curriculum religios interconfesional, prin realizarea unor sinteze ale elementelor comune, estompându-se deosebirile sau eventualele contradicţii;

Organizarea unui curriculum $\mathrm{cu}$ orientare monoconfesională (ortodoxă, catolică, protestantă etc.), în acord cu populaţia dominantă a populaţiei şcolare căreia i se adresează; lecţiile cu caracter interconfesional ar trebui să fie stabilite de comun acord de către reprezentanţii diferitelor culte, temele având un caracter general, îmbrăţişate de toţi: valorile religioase şi societatea, ecumenismul şi dialogul interreligios, laicatul şi Biserica etc.)

Autorul aduce şi argumente pertinente pentru necesitatea predării religiei la aceste vârste:

- Adolescenţa este etapa vertebrării şi verticalizării atitudinale şi axiologice a individului; este vârsta în care el caută

\footnotetext{
4 Autorul identifică şi punctele slabe, factorii de risc: astfel, pentru prima variantă, riscul ar consta în a aluneca în spre desfăşurări nespecifice disciplinei religie, pentru că elementele de istorie a religiei, metafizică religioasă, literatura religioasă etc. se studiază şi în cadrul disciplinelor clasice, ajungându-se la o disciplină cu caracter laic; pentru a doua opţiune: făcându-se abstracţie de elementele diferenţiatoare, elevii sunt private de cunoaşterea propriului cult; pe lângă această problemă, mai apare şi aceea că nu se ştie cine decide şi în funcţie de ce se stabilesc diferite marje de ,confesionalitate" ale conţinuturilor vehiculate la disciplina religie; pentru opţiunea a treia: este o cale mai adecvată, ajungându-se la un curriculum parţial comun, valabil pentru toate confesiunile.
} 
temeiuri, certitudini: valorile religioase pot oferi răspunsuri la întrebări metafizice, transcedentaliste sau mistice;

Este vârsta la care tânărul îşi construieşte şi delimitează identitatea culturală prin autopercepere, edificare spirituală, comparaţie cu alţii; fără o educaţie religioasă pe măsură, tânărul adolescent este privat de o dimensiune a existenţei sale ca individ şi colectivitate;

Tânărul este în căutarea unor repere stabile. În context postmodern, al destructurărilor continue, instabilităţilor, relativităţii şi relativizării, religia oferă orizonturi şi repere stabile. Valorile promovate de ea nu sunt supuse dubitativului, problematizării, fiind în acelaşi timp, adăugăm noi, un garant al trecerii prin milenii de istorie;

- $\quad$ Prin educaţia religioasă se întăreşte dorinţa cunoaşterii şi respectării alterităţii spirituale. Conturarea profilului spiritual al tânărului nu vine în contradicţie cu pluralismul, cu diversitatea, ci le potenţează, le dă substanţă, miez;

- Educaţia religioasă propune un set de valori, neerodabile, absolute, etern valabile. Tânărul are nevoie de ancore valorice, de puncte de sprijin: „A trăi în mundan, fără o zare a absolutului, înseamnă a trăi subuman, vegetativ şi în van." (Cucoş, p. $40)$;

- Valorile religioase îmbie la solidaritate şi comuniune, la difuziune de stări şi de simţire. Vârsta tinereţii caută împărtăşirea şi interrelaţionarea, punerea şi evaluarea eului, în faţa celorlalţi;

- $\quad$ Şcoala nu este doar un loc de alimentare cu informaţii / cunoştinţe, ci şi un spaţiu de formare de atitudini şi credinţe. Rămânând la limitele cognitivului nu facem nimic, în timp ce perspectiva religioasă propune o altfel de uzanţă, de abordare; presupune poziţionare, transcendere, deschiderea unor perspective mai înalte.

Privind programa şcolară la disciplina religie Giusseppina Zuccari (1997, p. 70.85, apud Cucoş, 2009, p. 258-260) identifică următoarele modele de programe: 
- $\quad$ Modelul de programare lineară sau prin obiective - se bazează pe taxonomiile clasice ale obiectivelor, cognitive, afective şi psihomotorii, fundamentat pe principiul că a instrui înseamnă a conduce individul la o schimbare de comportament;

- Modelul de programare „,circular-reticulară” - se bazează pe concepţia psihologică a dezvoltării şi învăţării, văzute ca procese continue, selective, dinamice; învăţarea nu mai reprezintă doar asimilare de informaţii, ci presupune raportarea noului învăţat la cel vechi, în virtutea principiului a învăţa să înveți;

- Modelul de programare ,prin proceduri” - presupune activizarea propriilor proceduri de cunoaştere şi stimularea elevilor $\hat{i}$ găsirea de soluții la situaţii problematice; important este mai mult procesul căutării, decât rezultatul acestuia;

- $\quad$ Modelul de programare ,prin concepte” - se bazează pe prescrierea unor itinerare de învăţare ce pornesc de la conţinuturi selecţionate şi organizate în mod clar, capabile de a-i conduce pe elevi la formalizare, la competenţa utilizării diferitelor coduri culturale;

- $\quad$ Modelul de programare prin „,situaţii” se bazează pe investigarea realităţii pe baza structurilor unor probleme ce se nasc în diferite situaţii de viaţă, inclusiv cele virtuale;

- Modelul de programare „prin perspective” - oferă şcolarului trăirea unei experienţe şcolare unitare, realizând contexte coerente cu modul în care copiii percep realitate. Perspectiva este o structură este o structură experienţială prin care se adună noi date despre realitate şi se confruntă vechiul cu noul, ştiutul cu neştiutul, se revalorizează experienţele anterioare cu cele noi;

- Post-programarea” - se referă la acele ajustări ale modelelor de programe care intervin după ce profesorii au convenit asupra noilor concepte, noilor mutaţii teoretice şi practice care au intervenit în timp. ${ }^{5}$

${ }^{5}$ Programa şcolară la disciplina religie, după Constantin Cucoş (2009, p. 259260) ar trebui să cuprindă: a) ; prezentarea generală a disciplinei b) obiectivele generale sau competenţele generale şi valorile spre care se centrează educaţia religioasă; c) obiectivele referenţiale, pentru fiecare an şcolar; d) principiile 
Un alt element important, cu valoare formativă în modelarea personalităţii tânărului din societatea actuală îl reprezintă valorile artistico-religioase. Religia poate deschide spiritul şi entuziasma, implicând trăire estetică, apelând la suporturi estetice pentru transmiterea unor mesaje specifice (pictură, sculptură, muzică, literatură, poezie etc.). „Dumnezeu s-a revelat mai întâi prin profeţi, aceşti fiind nu numai înţelepţi, ci şi artişti. Ceea ce aveau ei de spus nu rosteau în cuvinte banale, ci, de cele mai multe ori, în versuri" (Cucoş, 2009, p. 176). Şi Tudor Vianu (1968, p. 193) este de aceeaşi părere: „Contemplaţia artei creează o stare de suflet favorabilă religiei. Există o anumită coincidenţă a valorilor superioare ale culturii; un entuziasm comun care le învăluie pe toate deopotrivă şi care permite artei să regăsească sau, cel puţin, să pregătească atitudinea religiei."

În faţa artei religioase, tânărul poate trăi sentimente de înălţare sufletească de katharsis, de purificare, de identificare cu mesajele transmise de simboluri, icoane, picturi, sculpturi etc. Preoţii pot introduce şi utiliza în timpul cultului o serie de obiecte liturgice, care au şi o dimensiune estetică, cu puternic impact emoţional. De altfel, numeroase teme religioase pot fi regăsite în multiple ipostaze artistice.

\section{În loc de concluzii}

Concluzionăm că rolul educaţiei creştin religioase şi a Bisericii este unul crucial în formarea şi dezvoltarea armonioasă a personalităţii tinerilor din societatea actuală. Cele expuse mai sus sunt o pledoarie in acest sens. Vorbim, astfel, de primenirea

didactice generale corelate cu particularităţile disciplinei; e) structura tematică, pe capitole şi subcapitole, pentru fiecare an de studiu; f) sugestii tematice suplimentare pentru diferite categorii de elevi (supradotaţi, copii cu CES, minoritari confesionali) g) numărul de ore alocat fiecărui capitol sau temă; h) indicaţii/sugestii metodice privind procesele de predare, învăţare, evaluare a cunoştinţelor, priceperilor, deprinderilor, competenţelor; i) sugestii privind evaluarea performanţelor cu precizarea standardelor naţionale de performanță (nivel minim, mediu, maxim). 
duhovnicească a tinerilor în Biserică, la purificarea duhovnicească ce trebuie să se împlinească, în mod integral, prin învăţătura Bisericii lăsată moştenire de către Mântuitorul Iisus Hristos, care prin glasul Scripturii şi al Sfinţilor Părinţi ne arată nouă calea unică şi autentică ce duce la mântuire.

În credinţă creştină, Biserica este trupul Lui Iisus Hristos, prezent pe pământ. A veni la Biserică presupune mântuire şi iertare. În Biserică tinerii îşi pot purifica conştiinţele şi conduitele faţă de Divinitate şi faţă de semeni. Devenim mai buni în faţa lui Dumnezeu, a semenilor şi a noastră înşine. Prin urmare, Biserica şi educaţia religioasă propovăduită aici sunt surse de pietate de îndreptare morală şi sprijin şi consolare la nevoie. Nu în ultimul rând povaţa „Lăsaţi copiii să vină la mine şi nu-i opriţi, că Împărăţia Cerurilor este a acelora ca ei"(Matei, 19, 24) poate deveni un îndemn al preotului în a-i atrage pe tineri în sânul Bisericii şi al ceremoniilor religioase.

\section{Referinţe}

1. † Daniel, Patriarhul Bisericii Ortodoxe Române, Tinerii ortodocși mărturisitori ai iubirii lui Hristos şi misionari ai Bisericii. Disponibil: http://patriarhia.ro/tinerii-ortodocsi--marturisitori-ai-iubirii-lui-hristos-simisionari-ai-bisericii-8189.html, online 11.04.2016

2. Albu, G, Introducere într-o pedagogie a libertătiii, Iaşi, Edit. Polirom, 1998.

3. Cucoş, C., Educaţia religioasă. Repere teoretice şi metodice, Iaşi, Polirom, 1999.

4. Cucoş, C., Educaţia religioasă. Repere teoretice şi metodice, ediţia a II-a, Iaşi, Edit. Polirom, 2009.

5. Cucoş. C., Pedagogie, Iaşi, Edit. Polirom, 1996.

6. Cucoş. C., Educaţia. Dimensiuni culturale şi interculturale, Iaşi, Edit. Polirom, 2000.

7. Garrido, J.L.G., Fundamente ale educaţiei comparate, Bucureşti, Editura Didactică şi Pedagogică, 1995.

8. Gheorghiu, E.I., Religiozitate şi creştinism în România postcomunistă. Sociologie Românească, I (3), Universitatea din Bucureşti, 2003.

9. Horga, I., Educaţia religioasă în curriculum -ul şcolar. Modele şi tendinţe. Educaţia 21, 2, 126-127, 2005. 
10. IPS Daniel Ciobotea, Criza spirituală, în C. Coman, Ortodoxia sub presiunea istoriei, Bucureşti, Editua Bizantină, 1995.

11. Joiţa, E., Pedagogia. Ştiinţa integrativă a educaţiei, Iaşi, Editura Polirom, 1999.

12. Lipovetsky, G., Amurgul datoriei, Bucureşti, Editura Babel, 1996.

13. Macavei, E., Pedagogie. Teoria educaţiei, vol. I. Bucureşti, Editura Aramis, 2001.

14. Maliţa, M., Zece mii de culturi, o singură civilizaţie. Spre geomodernitatea secolului XXI, Bucureşti, Editura Nemira, 1998.

15. Neagu, A.R. Adolescenţii şi valorile credinţei. Disponibil: http://ziarullumina.ro/adolescentii-si-valorile-credintei-10975.html, online, 11.04.2016

16. Opriş, D., Opriş, M., Valori, modele şi aşteptări ale liceenilor din județul Alba, Cluj-Napoca, Editura Eikon, 2015.

17. Părintele Ieromonah Nicodim Petre, Lecţia de religie. Disponibil: https://www.monitorulsv.ro/Religie/2013-10-12/Tinerii-si-Biserica-I, online, 11.04.2016

18. Pr. lect. dr. Holbea Gh., Pr. lect. dr. Opriş, D., Lect. dr. Opriş, M., Diac. Jambore, G., Apostolat educaţional - Ora de religie - cunoaştere şi devenire spirituală, Bucureşti, Editura Basilica a Patriarhiei Române, 2010.

19. Valadier, P., L Église en procès, Paris, Flammarion, 1989.

20. Vianu, T., Estetica, Bucureşti, Editura pentru literatură, 1968.

21. Vianu. T., Filosofia culturii şi teoria valorilor, Bucureşti, Editura Nemira, 1998. 